DOI: https://doi.org/10.31933/dijemss.v2i2

Received: 20 September 2020, Revised: 27 October 2020, Publish: 28 December 2020

\begin{tabular}{|c|c|c|}
\hline PINASTISTR & $\begin{array}{l}\text { DIJEMSS } \\
\text { DINASTI INTERNATIONAL JOURNAL } \\
\text { OF EDUCATION MANAGEMENT AND } \\
\text { SOCIAL SCIENCE }\end{array}$ & $\begin{array}{r}\text { https://dinastipub.org/DIJEMSS } \\
\text { editor@dinastipub.org } \\
08117401455\end{array}$ \\
\hline
\end{tabular}

\title{
MEASUREMENT MODEL: INTERESTS OF BUYING A SAMSUNG BRAND SMARTPHONE WITH CELEBRITY ENDORSER AS AN ANTESEDENT VARIABLES IN THE ERA OF COVID-19
}

\author{
Ramdani Bayu Putra ${ }^{1}$, Nandan Limakrisna ${ }^{2}$, Hasmaynelis Fitri ${ }^{3}$ \\ 1) Student of Doctoral Program in Management, Faculty of Economics and Business, Putra \\ Indonesia University YPTK Padang, ramdhani_bayu@upiyptk.ac.id. \\ 2) Persada Indonesia University YAI, Indonesia \\ ${ }^{3)}$ Student of Doctoral Program in Management, Faculty of Economics and Business, Putra \\ Indonesia University YPTK Padang, hasmay@upiyptk.ac.id.
}

Corresponding Author: Ramdani Bayu Putra ${ }^{1}$

\begin{abstract}
The occurrence of the Covid-19 Pandemic around the world has had an impact on changing consumer patterns and behavior. This study aims to analyze the impact of price on the buying interest of Samsung smartphones with Celebrity endorsers as an antecedent variable. The sample in this study were 98 students of the Putra Indonesia University YPTK Padang. This study uses structural equation modeling (SEM) with SmartPLS 3 as an analysis tool. The results of the study found that celebrity endorser is a factor that influences price and buying interest. Meanwhile, the price does not influence buying interest, nor does it play a role in strengthening the influence of Celebrity endorsers on buying interest. For this reason, producers must improve the quality of competitive prices while also maintaining the use of celebrity endorsers in supporting the marketing of their products.
\end{abstract}

Keywords: Celebrity endorser, Price, Buying interest. 


\section{INTRODUCTION}

The massive spread of the coronavirus in all corners of the world, which we know as the Covid-19 Pandemic, has changed the pattern of life and behavior of the wider community. Both in work activities, production, marketing, and consumer behavior in meeting their daily needs. The number of restrictions on work activities in public spaces that must be done at home (Work from home) is a form of the government's way of breaking the chain of the spread of Covid-19. Besides wearing a mask, keep your distance and wash your hands every time. Some activities that also experience the impact of this condition are the teaching and learning process in schools and even up to universities. Teaching and learning activities are carried out at home online using the help of internet technology and the development of communication tools changing to cellphones or smartphones. This learning model is very useful and effective in helping educational institutions to be able to improve services and learning processes more flexibly without being limited by time, geographic location, and student or student attendance at school and on campus, (Bayu Putra dkk. 2019; Ramadhanu dkk. 2019; Fitri \& Putra, 2019).

The government also implements large-scale social restrictions (PSPB) to restrain the rate of movement of the deadly virus for areas or areas that enter the red zone. As an area that has a high spread of Covid-19, West Sumatra has also implemented PSPB from 22 April 2020 to 29 May 2020 and extended it until 7 June 2020. However, after 8 June 2020 West Sumatra, started to implement the normal life (new normal). Until August 2020 there were 2,751 cases of positive Covid-19 patients infected with Covid-19, (Wikipedia.com).

Apart from these problems, the phenomenon of changing the consumption behavior pattern of the very consumptive people has suddenly changed drastically, due to restrictions on social intersection within the community. Indirectly, the marketing concept related to the marketing mix has also experienced a shift, due to an extraordinary change in the external environment outside the company as a result of Covid-19, (Kotler, 2012; Limakrisna \& Susilo, 2012). People prioritize basic needs over other needs.

As explained above, the use of technology and communication tools plays a very important role in supporting the implementation of everyone's work activities. Also, in conditions that are full of technological developments, it is very possible to influence a person's behavior patterns, including consumptive behavior towards certain products, (Andhika Putra et al., 2019). One of the communication tools that are very developed and have advantages in terms of human mobility today is a Smartphone. Smartphones are mobile smart devices that are useful as communication tools but also have the ability for various activities, such as internet access, social media applications, and document management, (Firmansyah, dkk 2020; Kacetl and Klímová 2019). The use of smartphones has experienced an increasing trend since the Covid-19 Pandemic, because it allows all activities to be carried out easily, anytime, and anywhere. The following is the global growth data for the smartphone market share in the past 2 years: 
Table 1. Global Smartphone Quarterly Market Data (2019Q1 - 2020Q2)

\begin{tabular}{|c|c|c|c|c|c|c|c|}
\hline \multirow{2}{*}{ No } & \multirow{2}{*}{ Brands } & \multicolumn{3}{|c|}{$\mathbf{2 0 1 9}$} & \multicolumn{2}{|c|}{$\mathbf{2 0 2 0}$} \\
\cline { 3 - 8 } & & $\mathbf{Q 1}$ & $\mathbf{Q 2}$ & $\mathbf{Q 3}$ & $\mathbf{Q 4}$ & $\mathbf{Q 1}$ & $\mathbf{Q 2}$ \\
\hline 1 & Huawei\# & $17 \%$ & $16 \%$ & $18 \%$ & $14 \%$ & $17 \%$ & $20 \%$ \\
\hline 2 & Samsung & $21 \%$ & $21 \%$ & $21 \%$ & $18 \%$ & $20 \%$ & $20 \%$ \\
\hline 3 & Apple & $12 \%$ & $10 \%$ & $12 \%$ & $18 \%$ & $14 \%$ & $14 \%$ \\
\hline 4 & Xiaomi & $8 \%$ & $9 \%$ & $8 \%$ & $8 \%$ & $10 \%$ & $10 \%$ \\
\hline 5 & Oppo & $8 \%$ & $9 \%$ & $9 \%$ & $8 \%$ & $8 \%$ & $9 \%$ \\
\hline 6 & vivo & $7 \%$ & $8 \%$ & $8 \%$ & $8 \%$ & $7 \%$ & $8 \%$ \\
\hline 7 & Lenovo\#\# & $3 \%$ & $3 \%$ & $3 \%$ & $3 \%$ & $2 \%$ & $3 \%$ \\
\hline 8 & Others & $24 \%$ & $24 \%$ & $21 \%$ & $23 \%$ & $22 \%$ & $16 \%$ \\
\hline
\end{tabular}

Source: www.counterpointresearch.com/global-smartphone-share/, the Year 2020

The data above illustrates the global market share of some of the top smartphone brands, where Huawei occupies the top place throughout the 2019 to 2020 quarter with the fluctuating marketing trend and in 2020 the marketing of its products is up to $20 \%$. In the second place, the Samsung brand smartphone can be said to be relatively stable in the 2019 quarter and decreased in the 2020 quarter with a range of $20 \%$ in 2020, third place and so on followed by Apple, Xiaomi, Oppo, Vivo, Lenovo, and other brands where product marketing is below $20 \%$. This data shows that the impact of Covid-19 is more pronounced on small branded smartphones that tend to have a lower online presence and tend to serve the entrylevel segment more. Meanwhile, Huawei's presence in China has surpassed Samsung to lead the global smartphone market. For smartphone marketing at the national level, it can be seen in the following table:

Table 2. Indonesia: Top Smartphone Vendors in Q3 2019

\begin{tabular}{|c|c|c|c|c|c|}
\hline No & Vendor & $\begin{array}{c}\text { Q1 2020 } \\
\text { Shipments } \\
\text { Volume }\end{array}$ & $\begin{array}{c}\text { Q1 2020 } \\
\text { Market } \\
\text { Share }\end{array}$ & $\begin{array}{c}\text { Q1 2019 } \\
\text { Shipments } \\
\text { Volume }\end{array}$ & $\begin{array}{c}\text { Q1 2019 } \\
\text { Market } \\
\text { Share }\end{array}$ \\
\hline 1 & Samsung & 58.3 & $21.1 \%$ & 71.9 & $23.0 \%$ \\
\hline 2 & Huawei & 49.0 & $17.8 \%$ & 59.1 & $18.9 \%$ \\
\hline 3 & Apple & 36.7 & $13.3 \%$ & 36.8 & $11.8 \%$ \\
\hline 4 & Xiaomi & 29.5 & $10.7 \%$ & 27.8 & $8.9 \%$ \\
\hline 5 & Vivo & 77.8 & $9.9 \%$ & 23.2 & $7.4 \%$ \\
\hline 6 & Others & 275.8 & $100.0 \%$ & 312.3 & $100.0 \%$ \\
\hline
\end{tabular}

Source: IDC Quarterly Mobile Phone Tracker, the Year 2020

Based on the data above, the smartphone market share in the country for the last 2 (two) years in 2019 and 2020, the top places are led by smartphones from the Samsung brand, followed by Huawei, Apple, Xiaomi, Vivo, and other brands. When compared to the global level market share is led by the Huawei brand, but nationally the Samsung brand gets more attention from the public or smartphone users. The impact of the Covid-19 Pandemic was also seen in the decline in the smartphone market share, such as Samsung in 2019 the market share was $23 \%$ and decreased in 2020 to $21.1 \%$, likewise for the Huawei brand, which also experienced a decrease in market share from 18.9 in 2019 to $17.8 \%$ in 2020. This also happened to certain other brands, but Apple, Xiaomi, and Vivo brands experienced an increase in market share in 2020. This data indicates and proves that the marketing strategy used by the Samsung brand smartphone is more competitive than other competitors by using 
celebrity endorser services at affordable prices that have been proven effective in increasing prices and consumer buying interest.

Research on buying interest has been carried out, such as Research (-The Appeal of Celebrity Endorsers and Halal Certificates on Customers' Buying Interest,\| 2015), which examines The Appeal of Celebrity Endorsers and Halal certificates on Customers' Buying Interest, which examines The Appeal of Celebrity Endorsers and Halal certificates on Customers' Buying Interest, which examines The Appeal of Celebrity Endorsers and Halal certificates on Customers' Buying Interest, while Madiawati and Pradana (2016) also research on Celebrity and halal certificates factors influence on customers. 'buying interest. Research that also examines the buying interest of Samsung brand smartphones using factors that influence it, such as country of origin and global brand image, (Annisa, 2017; Sopiyan \& gun Gumelar, 2019; Tati, 2015). Furthermore, research by Andi et al. (2020); Sopiyan and Gumelar (2019), examined purchase interest on smartphones using celebrity endorsement factors, product quality, product design, brand equity, country of origin, brand image, ad attractiveness, and price. Another study by Foster (2019) assesses the effect of product quality and price on purchase intention with risk as an intervening variable, while Rahmanullah (2018) examines the effect of product quality, price, and supporting infrastructure on perceived value and interest in buying electric motorbikes. Furthermore, research (Ali, 2019) examines building repurchase intention and purchase decision: brand awareness and brand loyalty analysis.

Based on the problems and differences in research models both in terms of the use of variables and products understudy, this study focuses on celebrity endorsers as factors that influence the interest in buying Samsung brand smartphones, either directly or indirectly through the price variable as an intervening variable.

\section{LITERATURE REVIEW}

The development and advancement of technology and information systems today have had an impact on changing the behavior and lifestyle of all people in the world. Especially after the outbreak of the Covid-19 Pandemic around the world, it has had an impact on the use of technology and communication tools in the form of smartphones and has increased their use at all levels of society. Thus, smartphones are said to be smart devices that are useful for humans in addition to communicating, but also capable of carrying out various activities, such as internet access, social media applications, and document processing, (Jeng et al., 2010), (Lin et al., 2017). Starting from elementary school children (SD) to universities for online learning needs, to business people, employees, and the wider community to support their work activities. Especially in the field of education, online distance learning (PJJ) using smartphones for students is very helpful in following all the learning processes that have been given by the teacher (Jeng et al., 2010). Through smartphones, students can search for learning resources more optimally and use learning applications whenever and wherever, (Lan et al., 2010), (Cha \& Seo, 2018). 


\section{Buying interest}

Purchase interest is something that arises after receiving stimulation from the product he sees, then the desire to buy and own it appears (Kotler \& Armstrong, 2018), (Limakrisna \& Supranto, 2007; Limakrisna \& Susilo, 2012). The decision to consume the product or service arises after the consumer takes a series of actions such as trying the product and after that, there is a desire to like or dislike the product or service. Love and pleasure towards the product or service, when consumers find good quality and high satisfaction with their expectations of the product. Others argue that purchase intention is a component of consumer behavior, and the tendency to act before a decision is made. This decision process is obtained through learning and thinking that shapes perceptions and creates motivation, which ends with meeting their needs or making purchases (Zou, 2018). Assessment of purchase interest variables uses indicators consisting of, a). transactional interest, b). referential interest, c). preferential interests and d). explorative interest, (Japarianto \& Adelia, 2020).

\section{Celebrity Endorser}

Celebrity endorsers are an advertising approach that can provide the power to enhance the image and identification of a celebrity in promoting a product or company, (Dharma \& Iskandar, 2017). Another opinion Andi et al. (2020), states that the use of celebrities or artists in advertisements is intended to make the advertised products (goods or services) easier for consumers to remember. Besides, the use of celebrity endorsers also aims to convey advertising messages from products through famous personal figures such as actors, artists, or athletes who are known to the public and become idolized because of their achievements (Jatmika, M,. A, 2017). The celebrity endorser variable in this study was measured using the indicators in Sarah, dkk (2019) which include a). credibility, b). attractiveness and d). suitability.

\section{Price}

Prices are monetary units or other measures (including other goods and services) that are exchanged to obtain ownership rights or use of certain goods or services, (Tjiptono, 2019). Price is also said, the amount of money needed to get a combination of products and services, (Amron, 2018). In other words, consumers will consider the price along with the benefits or the level of satisfaction they get. Another opinion states that consumers at a certain price level will compare the benefits with the price level, if the benefits felt by consumers increase, the value or price to be paid will increase as well (Li, 2013), (Novansa \& Ali, 2017). Price is also said to be one of the determinants of a company's success because price determines how much profit a company will get from selling its products in the form of goods or services (Brata et al., 2017). Often in determining the value of a good or service, consumers compare the ability of a good or service to meet their needs with the substitute ability of the goods or services. The price assessment in this study refers to the indicators in research Anon (2018), namely a). Range of prices with consumer purchasing power b). Price competitiveness with similar products and c). Price match with quality.

The following is a research conceptual framework that describes the relationship between variables as well as an overview of existing research hypotheses: 


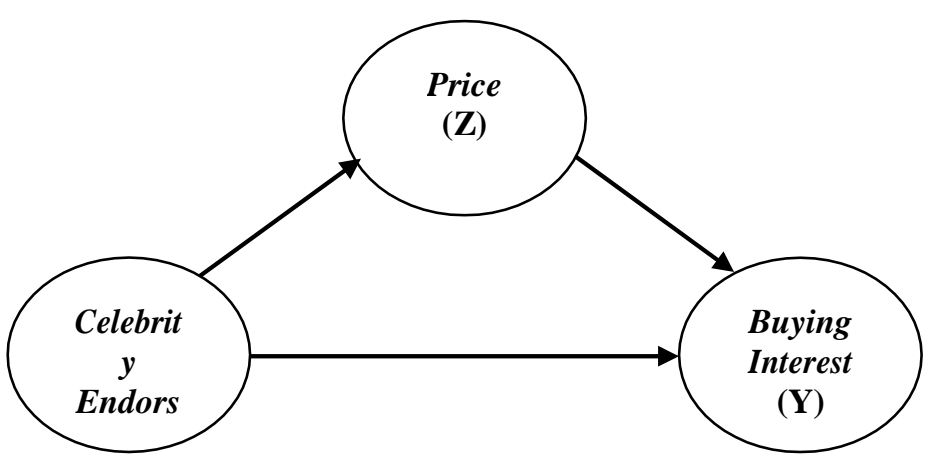

Figure 1. Conceptual framework

Based on the problems and theoretical study and conceptual framework, the research hypothesis is as follows:

1) Celebrity endorsers have a positive and significant effect on buying interest.

2) Celebrity endorser has a positive and significant effect on the price

3) Price has a positive and significant effect on buying interest.

4) Celebrity endorsers have a positive and significant effect on buying interest through price.

\section{RESEARCH METHODS}

The research model is causal, namely research that assesses the causal relationship between a certain independent variable and a certain dependent variable. The research data collection was conducted using a survey method by distributing questionnaires to respondents who have been determined by the researcher. To provide an understanding of research, research variables include the variable Celebrity endorser $\left(\mathrm{X}_{1}\right)$, price $(\mathrm{Z})$, and purchase interest (Y). The population of this study was all students of the Management Department of the Putra Indonesia University YPTK Padang, with a total of 4,213 people. While the sample in this study was determined using the Slovin formula with a precision level of $10 \%$, the number of samples can be obtained:

The data testing technique in this study uses structural equation modeling (SEM) using SmartPLS 3 in testing the research hypothesis. Data testing techniques using SmartPLS 3, divided into two parts. The first part of testing the Outer model, namely the measurement model to assess the validity of all indicators in each research variable. The second part of the 
results of data testing is related to the assessment of the research hypothesis (Abdillah \& Jogiyanto, 2015).

\section{FINDINGS AND DISCUSSION}

From the results of data testing using SmartPLS 3, the output includes visuals or images that explain the relationship between research variables or research hypotheses. In the picture, we will also be able to find out each loading factor value or the validity of each question item or indicator of each research variable. Can be seen the value of the regression coefficient to measure each of the existing research hypotheses. While the second form of output is in the form of a table that explains whether the research hypothesis is accepted or not. The following is a summary of the results of data testing with SmartPLS 3:

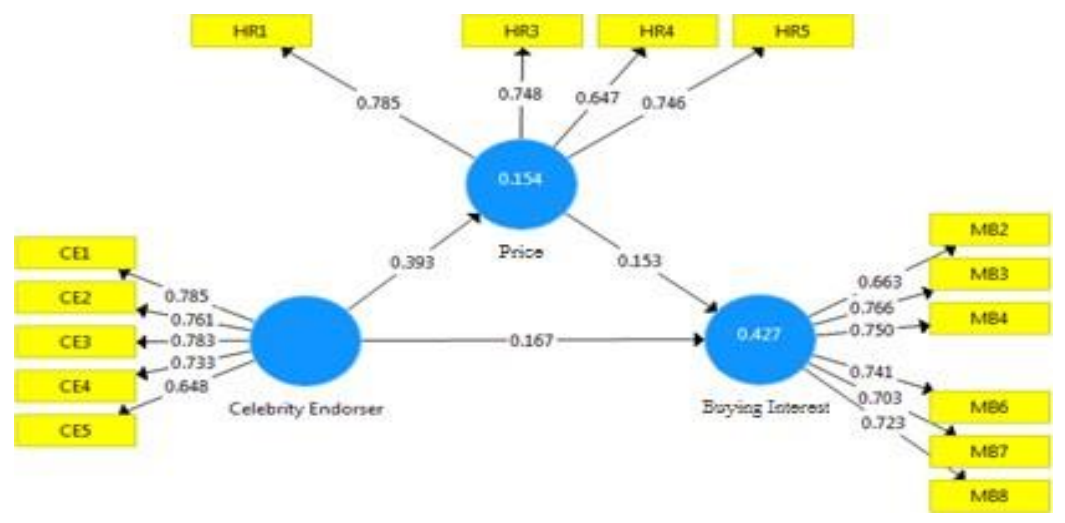

Figure 2. Full Model

From the picture of the full model above, it can be seen that all research variables which include the celebrity endorser variable, price, and purchase interest variables have indicators or statement items that form each variable. Where already has a loading factor value greater than 0.5 which indicates all question items or indicators are valid or measurable. Meanwhile, the value of the regression coefficient that is shown from a variable to another variable is the value of the magnitude of the influence given by that variable to other variables following the research hypothesis that has been prepared. Furthermore, the second output is the table of results for inner weights to assess or answer the hypothesis:

Table 3. Result for Inner Weights

\begin{tabular}{|l|c|c|c|c|}
\hline \multicolumn{1}{|c|}{ Description } & $\begin{array}{c}\text { Original } \\
\text { Sample }\end{array}$ & T Statistics & P-Velue & Information \\
\hline $\begin{array}{l}\text { Celebrity endorser }->\text { Buying } \\
\text { interest }\end{array}$ & 0.167 & 2.018 & 0.044 & Hypothesis Accepted \\
\hline Celebrity endorser $->$ Price & 0.393 & 4.444 & 0.000 & Hypothesis Accepted \\
\hline Price -> Buying interest & 0.153 & 1.352 & 0.177 & Hypothesis Rejected \\
\hline Celebrity endorser $>>$ Price -> & 0.060 & 1.178 & 0.240 & Hypothesis Rejected \\
\hline
\end{tabular}




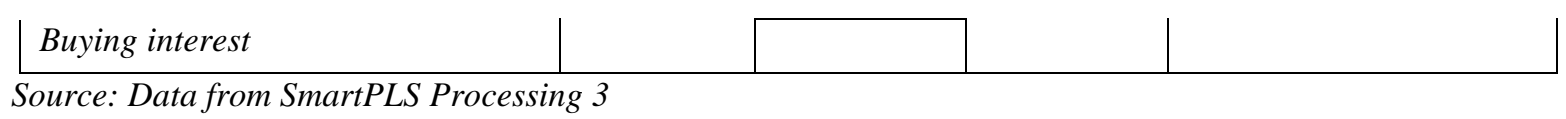

\section{The influence of Celebrity endorsers on buying interest}

The findings of the SmartPLS 3 test results found the regression coefficient value of 0.167 celebrity endorser on purchase interest with a statistical T value of 2.018 and P-value of 0.044 . Where the $\mathrm{T}$ statistical value is greater than $\mathrm{T}$ table $(2.018>1.96)$ and the $\mathrm{P}$-value $<0.05(0.044$ $<0.05)$. This states that there is a significant effect of celebrity endorsers on the interest in buying Samsung brand smartphones in students of the Putra Indonesia University YPTK Padang in online learning in the Covid-19 Pandemic era so that the research hypothesis can be accepted or proven. These results explain it turns out that celebrity endorsers in this study have a good role in conveying the message of the value of the product or service expected by the seller or product. In other words, students have high attention from the use of celebrity endorsers in a smartphone product in determining their buying interest in the Samsung brand smartphone. This finding is in line with the opinion of Andi et al. (2020), who states that the use of celebrities or artists in advertisements is intended to make the advertised products (goods or services) easier for consumers to remember. Other literature also reveals that the effectiveness of celebrity endorsers in marketing communication can be increased by matching celebrity images with product attributes (McCormick 2016; Parmar, Ghuman, and Mann 2020; Roy 2018; Um 2018). The results of the study support the research of Madiawati and Pradana (2016); Rachmat, at al (2019); Andi et al. (2020) which states that celebrity endorsers have an influence and role in increasing and influencing purchase interest.

\section{The Influence of Celebrity Endorsers on Prices}

The results of testing with SmartPLS 3 showed that there was a significant effect of celebrity endorsers on the price of Samsung brand smartphones for students at Putra Indonesia University YPTK Padang. Where the regression coefficient is 0.393 with a T-statistic value of 4.444 and a $\mathrm{P}$-value of 0.000 . Where the $\mathrm{T}$ statistical value is greater than the $\mathrm{T}$ table $(4.444>$ 1.96) and the P-value $<0.05(0.000<0.05)$, so that the research hypothesis can be accepted or proven. This finding states that product prices also depend on the ability of celebrity endorsers to form good product characters and convey messages of the value of the product. Chan, Leung ng, and Luk (2013), said that celebrity endorser is a common marketing communication strategy to build a brand image. Rismawan and Purnami (2017) state that the use of the Celebrity Endorser and the determination of Price Discounts as promotional tools are expected to increase sales. Varghese (2019), who says celebrity endorsers are considered a modern marketing today and in the future that targets main targets such as teenagers or certain groups who are considered to have awareness of brands and prices. The findings of this hypothesis are different from previous studies that assessed the influence or relationship of celebrity endorsers with the brand image, such as research by Abirami and Krishnan (2015); Anon (2013); Megayani and Marlina (2019); Mukherjee (2011); Sam and Rajagiri (2019); Shoeb and Khalid (2014); Varghese (2019), (Putra et al., 2020). 


\section{Effect of Price on Buying Interest}

The results of the calculations in the results for inner weights table show that price does not have a significant effect on buying interest in Samsung brand smartphones for students at Putra Indonesia University YPTK Padang. With a regression coefficient value of 0.153 with a statistical $\mathrm{T}$ value of 1.352 and a $\mathrm{P}$-value of 0.177 . Where the $\mathrm{T}$ statistical value is small from $\mathrm{T}$ table $(1.352<1.96)$ and the $\mathrm{P}$ value> $0.05(0.177>0.05)$, so the hypothesis cannot be proven or not accepted. These results also indicate that the price as a monetary unit that consumers must accept and pay for a product does not have a significant effect on purchase intention. This condition is of course directly related to the ongoing Covid-19 Pandemic, many restrictions on community interaction in carrying out their work to break the chain of spreading this virus. However, it has also had an impact on the income or income of the majority of the community, so that people are more concerned with meeting their primary or basic needs compared to meeting other complementary needs. Goyal et al. (2013), said that price perceptions determine consumer buying interest in an item. This research is in line with the research of Foster and Johansyah (2019), which states that prices do not affect purchase intention and contradicts the research of Rahmanullah and Nurjanah (2018), (Putra et al., 2020), which found that price is a factor that determines purchase interest.

\section{The influence of Celebrity endorser on Buying interest through Brand image}

This hypothesis assesses the indirect effect of celebrity endorsers on purchase interest through price or assesses the extent to which the role of price as an intervening variable in strengthening the influence of celebrity endorsers on the purchase interest of Samsung brand smartphones in students of Putra Indonesia University YPTK Padang. Where the regression coefficient is 0.060 with a statistical $T$ value of 1.178 and a P-value of 0.240 . It can be seen that the $\mathrm{T}$ statistical value is small from the $\mathrm{T}$ table $(1.17<1.96)$ and the $\mathrm{P}$ value> $0.05(0.240>0.05)$. It can be concluded that the research hypothesis cannot be proven or the hypothesis is not accepted. Therefore it can be concluded that celebrity endorsers under certain conditions are not proven to be mediated by price in increasing purchase interest. Jatmika, M,. A (2017) states that celebrity endorsers basically aim to convey advertising messages from products through wellknown personal figures such as actors, artists, or athletes who are known to the public and become idolized because of their achievements, which in turn can accompany consumers' thoughts to have an interest in the product. The results of this study are different from the findings of Rismawan and Purnami (2017), which make price a moderating variable in strengthening the influence of celebrity endorsers on purchase interest. Where the research findings state that the price is not able to moderate the effect of celebrity endorsers on buying interest.

\section{CONCLUSION}

The results of the study found that the celebrity endorser is a factor that influences and determines the price and interest in buying Samsung brand smartphones for students of the Putra Indonesia University YPTK Padang in supporting online learning in the Covid-19 Pandemic era. However, this study also found that price was not a determining factor for purchase interest and 
was also not a factor capable of mediating or strengthening the influence of celebrity endorsers on the purchase interest of Samsung brand smartphones in students of Putra Indonesia University YPTK Padang. These findings indicate that the Covid-19 Pandemic has changed consumer behavior patterns in meeting their needs, especially those related to online learning. Producers or vendors must try to take into account the correct pricing as well as being a factor that supports the role of celebrity endorsers and shapes consumer patterns and behavior through the messages they convey.

\section{REFERENCE}

Abdillah, W., \& Jogiyanto, H. (2015). Partial Least Square (PLS) Alternatif Structural Equation Modeling (SEM) dalam Penelitian Bisnis. In book: Vol. I (Issue 1, pp. 160-196).

Abirami, U., \& Krishnan, J. (2015). Role of celebrity - Brand congruency in building brand image. International Journal of Economic Research, 12(1), 37-46.

Ali, H. (2019). Building Repurchase Intention and Purchase Decision: Brand Awareness and Brand Loyalty Analysis (Case Study Private Label Product in Alfamidi Tangerang). Saudi Journal of Humanities and Social Sciences, 04(09), 623-634. https://doi.org/10.36348/sjhss.2019.v04i09.009

Amron, A. (2018). The Influence of Brand Image, Brand Trust, Product Quality, and Price on the Consumer's Buying Decision of MPV Cars. European Scientific Journal, ESJ, 14(13), 228. https://doi.org/10.19044/esj.2018.v14n13p228

Andhika Putra, R., Ridwan, M., Melmusi, Z., Bayu Putra, R., \& Hutari Mulyani, S. (2019). The Differences of Consumer Behaviors Towards Merantau Student and Local Student. KnE Social Sciences, 3(14), 41. https://doi.org/10.18502/kss.v3i14.4297

Andi, Suyono, Hafis, P. Al, \& Hendri. (2020). PENGARUH CELEBRITY ENDORSER, KUALITAS PRODUK, DESAIN PRODUK TERHADAP MINAT BELI SMARTPHONE ASUS PADA MAHASISWA PELITA INDONESIA. Jurnal Ilmiah Manajemen, 8(1), 2338.

Annisa, N. (2017). Pengaruh Country Of Origin Dan Brand Image Terhadap Minat Beli Pada Produk Smartphone Samsung (Studi Pada PT Samsung Electronic Indonesia Cabang Pekanbaru). Jom Fisip, 4(2), 1-8.

Bayu Putra, R., Elfiswandi, Ridwan, M., Rizki Mulyani, S., Syahrullah Ekajaya, D., \& Andhika Putra, R. (2019). Impact of Learning Motivation, Cognitive and Self-Efficacy in Improving Learning Quality E-Learning in Industrial Era 4.0. Journal of Physics: Conference Series, 1339(1). https://doi.org/10.1088/1742-6596/1339/1/012081

Brata, H. B., Husani, S., \& Ali, H. (2017). The Influence of Quality Products, Price, Promotion, and Location to Product Purchase Decision on Nitchi at PT. Jaya Swarasa Agung in Central Jakarta. Saudi Journal of Business and Management Studies, 2(4B), 433-445. https://doi.org/10.21276/sjbms

Cha, S. S., \& Seo, B. K. (2018). Smartphone use and smartphone addiction in middle school students in Korea: Prevalence, social networking service, and game use. Health Psychology Open, 5(1). https://doi.org/10.1177/2055102918755046

Chan, K., Leung ng, yu, \& Luk, E. K. (2013). Impact of celebrity endorsement in advertising on brand image among Chinese adolescents. Young Consumers, 14(2), 167-179. https://doi.org/10.1108/17473611311325564 
Dharma, K. N. A., \& Iskandar, D. (2017). Pengaruh Celebrity Endorser Jkt48 Terhadap Minat Beli Konsumen Im3 Play (studi Kasus Pada Pengunjung Teater Jkt48 Periode 21 Februari 2016). EProceedings of Management, 4(2), 1304-1311.

Firmansyah, R. O., Hamdani, R. A., \& Kuswardhana, D. (2020). The use of smartphone on learning activities: Systematic review. IOP Conference Series: Materials Science and Engineering, 850(1). https://doi.org/10.1088/1757-899X/850/1/012006

Fitri, H., \& Putra, R. B. (2019). the Impact of Learning Culture on Readiness To Online Learning Through Learning Satisfaction As Intervening Variable in the Industrial Era 4.0. Jurnal Apresiasi Ekonomi, 7(3), 309-316. https://doi.org/10.31846/jae.v7i3.248

Foster, B. (2019). The effect of product quality and price on buying interest with risk as intervening variables (study on Lazada.com site users). International Journal of Innovation, Creativity and Change, 9(12), 66-78. https://www.scopus.com/inward/record.uri?partnerID=HzOxMe3b\&scp=85079660201\&ori gin=inward

Foster, Bob, \& Johansyah, M. D. (2019). The effect of product quality and price on buying interest with risk as intervening variables (study on Lazada.com site users). International Journal of Innovation, Creativity and Change.

Goyal, A., Maity, M., Thamizhvanan, A., \& Xavier, M. J. (2013). Determinants of customers' online purchase intention: An empirical study in India. Journal of Indian Business Research. https://doi.org/10.1108/17554191311303367

Japarianto, E., \& Adelia, S. (2020). PENGARUH TAMPILAN WEB DAN HARGA TERHADAP MINAT BELI DENGAN KEPERCAYAAN SEBAGAI INTERVENING

VARIABLE PADA E-COMMERCE SHOPEE. Jurnal Manajemen Pemasaran, 14(1), 3543. https://doi.org/10.9744/pemasaran.14.1.35-43

Jatmika, M,. A, . S. (2017). Perikanan Promosi \& Aspek Tambahan Komunikasi Pemasaran Terpadu. Jilid 1, Edisi 5, Jakarta: Erlangga, 2003., 5, 464.

Jeng, Y. L., Wu, T. T., Huang, Y. M., Tan, Q., \& Yang, S. J. H. (2010). The add-on impact of mobile applications in learning strategies: A review study. Educational Technology and Society, 13(3), 3-11.

Kacetl, J., \& Klímová, B. (2019). Use of smartphone applications in english language learningA challenge for foreign language education. In Education Sciences (Vol. 9, Issue 3). https://doi.org/10.3390/educsci9030179

Kotler, P. (2012). Marketing management/Philip Kotler, Kevin Lane Keller. Pearson Education International.

Kotler, P., \& Armstrong, G. (2018). Principles of Marketing| Pearson. In Pearson.

Lan, Y. J., Sung, Y. T., Tan, N. chun, Lin, C. P., \& Chang, K. E. (2010). Mobile-devicesupported problem-based computational estimation instruction for elementary school students. Educational Technology and Society, 13(3), 55-69.

Li, J. (2013). Factors affecting customer satisfaction and customer loyalty towards Belle Footwear Company in Lanzhou City, Gansu Province of the People's Republic of China. Journal of Business and Management, 14(2), 41-48.

Limakrisna, N., \& Supranto, J. (2007). Perilaku konsumen dan strategi pemasaran. Mitra Wacana Media.

Limakrisna, N., \& Susilo, W. H. (2012). Manajemen Pemasaran Teori Dan Aplikasi Dalam 
Bisnis. In MANAJEMEN PEMASARAN Teori dan Aplikasi Dalam Bisnis.

Lin, C. Y., Chao, Y. C., \& Tang, T. W. (2017). Why not be -smarterl? Examining the factors that influence the behavioral intentions of non-smartphone users. Industrial Management and Data Systems, 117(1), 32-49. https://doi.org/10.1108/IMDS-07-2015-0319

Madiawati, P. N., \& Pradana, M. (2016). Celebrity and halal certificates factors influence on customers' buying interest. Actual Problems of Economics, 177(3), 109-116.

McCormick, K. (2016). Celebrity endorsements: Influence of a product-endorser match on Millennials attitudes and purchase intentions. Journal of Retailing and Consumer Services, $32,39-45$.

Megayani, M., \& Marlina, E. (2019). Pengaruh Celebrity Endorsement terhadap Purchase Intention melalui Brand Image sebagai Variabel Intervening. Jurnal Akuntansi Dan Manajemen, 16(01), 175-193. https://doi.org/10.36406/jam.v16i01.277

Mukherjee, D. (2011). Impact of Celebrity Endorsements on Brand Image. SSRN Electronic Journal. https://doi.org/10.2139/ssrn.1444814

Novansa, H., \& Ali, H. (2017). Purchase Decision Model: Analysis of brand image, brand awareness and price (Case study SMECO Indonesia SME products). Saudi Journal of Humanities and Social Sciences, 2(8), 621-632.

Parmar, Y., Ghuman, M. K., \& Mann, B. J. S. (2020). The Match-up Between Celebrity Associations and Product Type. Journal of Creative Communications, 15(1), 65-89.

PENGARUH KUALITAS PELAYANAN DAN HARGA TERHADAP LOYALITAS PELANGGAN PENGGUNA APLIKASI GOJEK (STUDI PADA PENGGUNA LAYANAN GO-RIDE DI KOTA MANADO). (2018). Jurnal EMBA: Jurnal Riset

Ekonomi, Manajemen, Bisnis Dan Akuntansi, 6(4). https://doi.org/10.35794/emba.v6i4.21062

PRATAMA, R. A. (2014). ANALISIS PENGARUH CITRA MEREK, DAYA TARIK IKLAN, DAN HARGA TERHADAP MINAT BELI SMARTPHONE NOKIA LUMIA (Studi Pada Konsumen Smartphone di Kota Semarang). Repositori Universitas Diponegoro, 1-52.

Putra, R. B., Yeni, F., Fitri, H., \& Hutapea, N. (2020). The Role of Consumer Satisfaction in Mediating Service Quality and Brand Image on Consumer Loyalty. SENTRALISASI, 9(2), 108-119.

Rachmat, R. A. H., Hurriyati, R., \& Sultan, M. A. (2019). Product Differentiation, Celebrity Endorsement and Purchase Intention: Case Study of Makuta Cake Bandung, West Java, Indonesia. Global Business and Management Research, 11(1), 275-283.

Rahmanullah, E S. (2018). Influence of product quality, price and supporting infrasturcture to perceived value and interest in buying of electric motorcycle. In MATEC Web of Conferences (Vol. 215). https://doi.org/10.1051/matecconf/201821502006

Rahmanullah, Edwin Sholeh, \& Nurjanah, S. (2018). Influence of product quality, price and supporting infrasturcture to perceived value and interest in buying of electric motorcycle. MATEC Web of Conferences. https://doi.org/10.1051/matecconf/201821502006

Ramadhanu, A., Bayu Putra, R., Syahputra, H., Husna Arsyah, R., \& Permata Sari, D. (2019). Learning Satisfaction Analysis of Online Learning Readiness with Learning Culture and Character Strength as Antecedent Variables. Journal of Physics: Conference Series, 1339(1). https://doi.org/10.1088/1742-6596/1339/1/012080

Rismawan, I., \& Purnami, N. (2017). PERAN PRICE DISCOUNT MEMODERASI 
PENGARUH PRODUCT KNOWLEDGE DAN CELEBRITY ENDORSER TERHADAP PURCHASE INTENTION. E-Jurnal Manajemen.

Roy, S. (2018). Meaning transfer in celebrity endorsements: an explanation using metaphors. Journal of Marketing Communications, 24(8), 843-862.

Sam, P., \& Rajagiri, T. A. P. (2019). IMPACT OF CELEBRITY ENDORSEMENT ON BRAND IMAGE A STUDY ON COSMETIC INDUSTRY. In International Journal in Management and Social Science (Vol. 6).

Sarah, S., Rachman, A., \& Febrianti, T. (2019). PENGARUH FASHION LIFESTYLE, DESIGN, DAN SELEBRITY ENDORSER TERHADAP PURCHASE INTENTION. $E$ Jurnal STIE INABA, 18(03), 60-75.

Shoeb, A., \& Khalid, A. (2014). Impact of Celebrity Endorsements on Brand. International Journal Of Scientific \& Engineering Research, 5(12), 95-110.

Sopiyan, P., \& gun Gumelar, G. (2019). PENGARUH BRAND EQUITY DAN COUNTRY OF ORIGIN TERHADAP MINAT BELI PRODUK SMARTPHONE SAMSUNG (Studi Pada Mahasiswa Fakultas Ekonomi Universitas Majalengka). Jurnal Ilmiah Ekonomi Dan Keuangan Syariah, I, 19-35.

Tati, P. (2015). PENGARUH COUNTRY OF ORIGIN DAN GLOBAL BRAND IMAGE TERHADAP MINAT BELI DAN KEPUTUSAN PEMBELIAN (Survei pada Konsumen yang Membeli Smartphone Samsung Galaxy di Asia Tenggara). Jurnal Administrasi Bisnis S1 Universitas Brawijaya.

The appeal of celebrity endorsers and halal certificates on customers' buying interest. (2015). Journal of Administrative and Business Studies, 1(1). https://doi.org/10.20474/jabs-1.1.5

THE IMPACT OF CELEBRITY ENDORSEMENT ON BRAND IMAGE. (2013). Jurnal Riset Ekonomi, Manajemen, Bisnis Dan Akuntansi, 1(3). https://doi.org/10.35794/emba.v1i3.1887

Tjiptono, F. (2019). Perilaku Konsumen: Definisi, Domain, Determinan. Strategi Pemasaran Dalam Perspektif Perilaku Konsumen, 103.

Um, N.-H. (2018). What affects the effectiveness of celebrity endorsement? Impact of interplay among congruence, identification, and attribution. Journal of Marketing Communications, 24(7), 746-759.

Varghese, B. A. (2019). A STUDY ON THE IMPACT OF CELEBRITY ENDORSEMENT ON CONSUMER BUYING BEHAVIOUR TOWARDS APPAREL. INTERNATIONAL JOURNAL OF RESEARCH IN COMMERCE \& MANAGEMENT, 10, 13-17.

Zou, T. (2018). Online impulse buying behavior amongst undergraduate students in Tianjin, The People's Republic of China. ABAC Journal, 38(2), 94-113.

엄남현 (2017). What affects the effectiveness of celebrity endorsement? Impact of interplay among congruence, identification, and attribution. 